\title{
Conceptualizing industrial culture
}

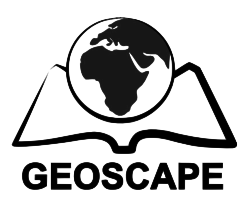

Jörn Harfst ${ }^{1, \bowtie}-$ Andreas Wust $^{2}-$ Robert Nadler $^{3}$

${ }^{1}$ University Graz, Department of Geography and Regional Science, Heinrichstrasse 36, 8010 Graz, Austria

${ }^{2}$ IfL - Leibniz Institute for Regional Geography, Schongauerstr. 9, 04328 Leipzig, Germany

${ }^{3}$ ILS - Research Institute for Regional and Urban Development, Brüderweg 22-24, 44135 Dortmund, Germany

凶joern.harfst@uni-graz.at

\begin{abstract}
So far, 'Industrial Culture' as a term has been widely used as a synonym for industrial heritage. Only recently, a re-interpretation of industrial culture has been discussed, which goes beyond heritage issues by including contemporary or upcoming cultural and creative resources, addressing directly the future development opportunities of regions. Whilst some aspects of this conceptual framework of industrial culture are already applied in some places, there is no comprehensive outline available yet. In the academic field so far no coherent concept can be found. The aim of this thematic issue is to foster a discussion on the state-of-the-art regarding the conceptualisation of industrial culture. This thematic issue has gathered contributions that respond to the following questions: the different understandings of the concept of industrial culture; the role of industrial culture in the context of a post-industrial society and a knowledge-based economy; the connection between industrial culture, regional development and regional identity, as well as the inter-linkages between traditional industrial sectors and creative industries. The contributions in this issue focus strongly on the connection between the industrial past, present and future, bringing together different academic view points on the topic. The issue maps out current research topics and poses new questions on dealing with the wide topic of industrial culture.
\end{abstract}

\section{Keywords}

Industrial culture, Europe,

Creative industries, De-Industrialisation, Regional development

Received:

9 March 2018

Received in revised form: 31 May 2018

Accepted:

5 June 2018

\section{Introduction}

What is 'Industrial Culture' and how does it impact realities in European regions, especially those characterised as (post-)industrial and being situated outside major metropolitan areas? How is this notion - that immediately brings very different pictures to people's minds - conceptualised and understood academically? And how could it be used to positively influence regional development, creating new opportunities in regions - not despite - but because of their distinct industrial past?

These were the initial questions raised by the guest editors of this special issue when preparing a scientific workshop ${ }^{1}$ in autumn 2016 at the Department of Geography and Regional Science at the University of Graz (Austria). The aim was to have an initial discussion among participants on the term industrial culture in the academic sphere, inviting European researchers from different disciplines to share their views on and experiences with the topic. The workshop was held in the context of the InduCult2.0 project, an European transnational co- operation project (INTERREG Central, 2016-2019) co-funded by the European Regional Development Fund, which fosters exchange between several Central European regions on the topic and potential of industrial culture (www.inducult.eu). The guest editors of this special issue have shaped and conducted their academic research along this project. The exchange in Graz underlined the different academic approaches to industrial culture, but also the shared aspects and elements. The discussions showed that the basic notion of industrial culture was rather clear when describing its individual elements, but that the ways to define and analyse industrial culture in a holistic way, remains a challenge. Issues such as understanding 'culture' or 'everyday culture', the role of industrial culture in the historical and present-day development of economies and societies, as well as what actions policy-wise might be considered to build more sustainable regions remain blurred. But, herein obviously lies also the fascination and challenge dealing with the broad topic of industrial culture. Some of the contributions from that workshop were invited to this special issue, thereby highlighting spe- 
cific academic perspectives on industrial culture. To us as guest editors falls the task to highlight shared characteristics and questions on the topic, often overlooked in the strict separation of academic disciplines. Especially an interdisciplinary term such as 'industrial culture' deserves the effort to foster dialogue across the disciplinary borders, in order to enhance our understanding of an important founding stone of the societies we live in today. We will frame the articles of this special issue with our own notion of industrial culture, based on our background as researchers in the field of regional development. Thereby, we involuntary put forward our own view on the topic, next to the perspectives of the other authors in this special issue. Against this backdrop, our editorial will not only introduce the articles of this volume, but also discuss the potential of 'industrial culture' as an instrument for regional development and especially for re-inventing (post-)industrial regions. Until today there is no common definition of this term, respectively a coherent concept. We argue, in line with the other authors of this issue, that industrial culture is integrated in the frame of economic, political, and social transition processes, thereby changing through time and bound to specific place-based social compositions. Hence, we will briefly try to illustrate the changes in the understanding of 'industrial culture' in different contexts for the last decades and highlight some theoretical approaches, putting forward issues such as 'tacit knowledge', recurring on existing knowledge, skills, and habits that are influencing the industrial culture of (post-)industrial regions. In a second line of thoughts we will briefly highlight the relevance of the topic in terms of current policies on European level and interconnected policy fields. Finally, we will introduce the articles collected for this volume.

\section{Understanding the diversity of the term industrial culture}

The term 'Industrial Culture' has no coherent definition, especially when taking into account different national contexts.It is often focused on the physical remains of former industrial sites and their preservation or re-utilisation, often as places for cultural events, education or other purposes (Rautenberg 2012; Harfst et al. 2016). This understanding of industrial culture, as captured e.g. in the German expression 'Industriekultur', focuses mostly on the tangible remains of industry, i.e. buildings, infrastructures and landscapes. Here the term has been initially used in a more narrow sense concern- ing a culture of industry in its purely material shaping. Thus, it is rather related to the terms 'Industrial Heritage' or 'Industrial Archaeology' (Pirke 2010), as this is the case in other Central European countries (e.g. in Czech Republic and Slovenia). This still prevailing focus comes despite early academic works that strived to open the narrow focus and also include the social dimension into the perspective on the industrial production and its social framing. For example, Glaser et al. (1980) defined industrial culture in a distinctly wider perception as the totality of living conditions among the pervading industrialisation, later widening it as the comprehensive (cultural) history of the 'machine-age' (Glaser 1981). Pirke (2010) enlarged the definition for an applied research on industrial culture by underlining the comprehensive history of the industrial age with its typical forms of life and society and the associated norms and values that made up the history and present form of the industrial cultural landscape. Additionally Rasmussen and Rauner (1996) discuss the topic of industrial culture in the relation to competitiveness. According to them, the 'industrial culture' concept would permit an analysis and understanding of hitherto unrecognised interrelationships between the dimensions of different industrial cultures and the process of technological innovation in international competition. Important dimensions would be social institutions, industrial organization, educational institutions, government policy and psychology.

Recently the 'Scientific Advisory Board for Industriekultur' in Saxony (Wissenschaftlicher Beirat 2010) recommended a reinterpretation and reevaluation of the 'industrial' age, in the context of a general change in the society's opinion on the historical importance of the industrial society. The view should be broadened from the past to an examination of the present and also to current development trends of the industrial society, including the relevant political and cultural phenomena that are active in them. Thus, an examination of the subject of 'Industrial Culture' is not only connected with the 'backward' view into the past, but also involves an inclusion of the present and future of industrial society. As a multidimensional issue, the discussion of industrial culture affects all social groups and institutions of the industrial society.

Contrary to the German discussion, the Englishspeaking research community has a clear terminological divide between 'Industrial Heritage' and 'Industrial Culture', the second clearly interlinked with an understanding of 'working class' culture, so a set of social characteristics and lifestyles constituted by the link between the industrial labour and soci- 


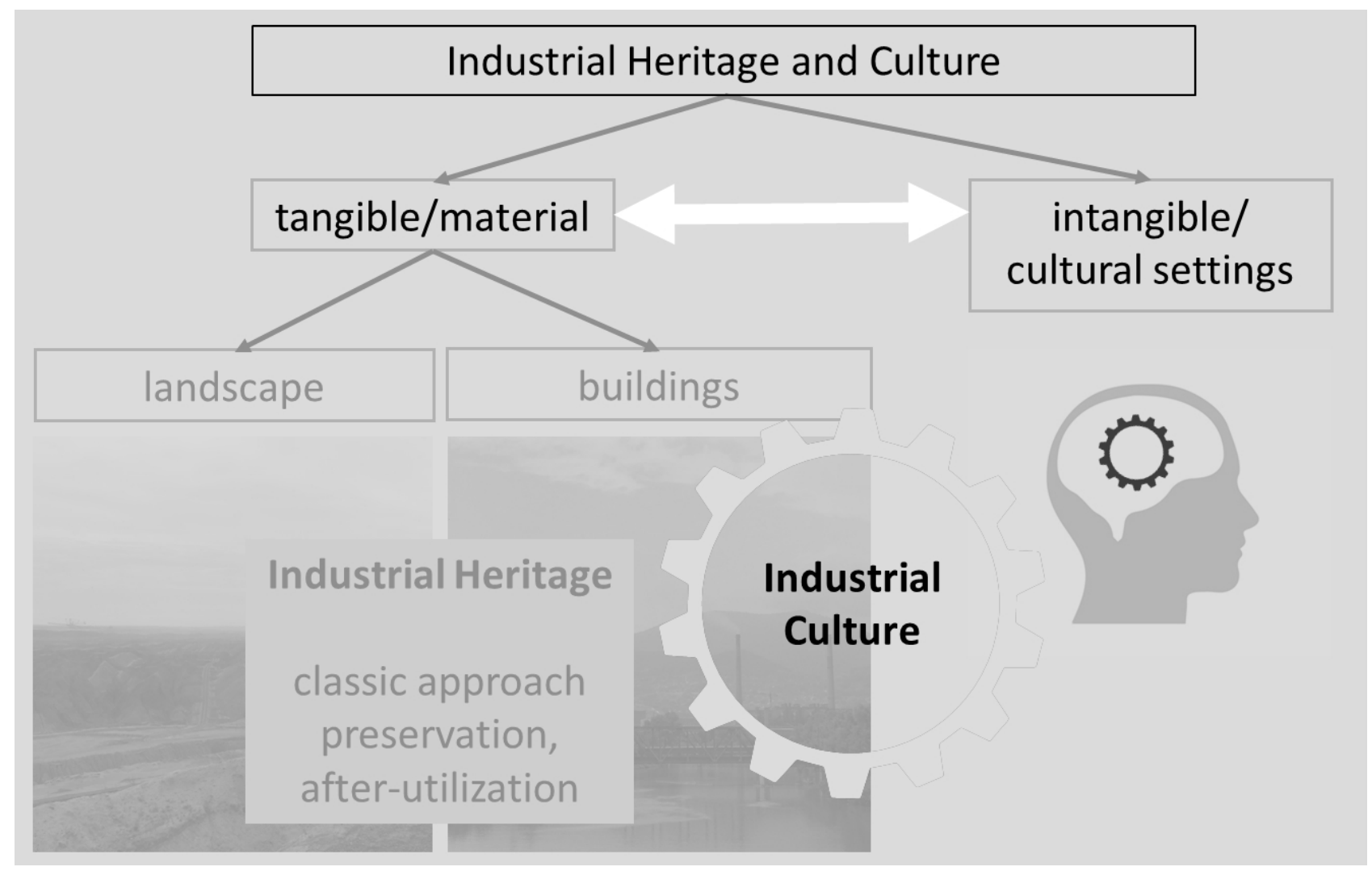

Fig. 1 Industrial heritage and industrial culture (textcolorcitfigHarfst et al. 2016

ety (cf. Fig. 1). In a more recent work, drawing upon Raymond Williams' work on culture ( 1980), Byrne (2002) stressed that the sentiments, which inform and construct 'ways of life' - indicated as 'industrial structure of feeling' - would remain a feature for many social groups beyond the period of industrialism. In this context he emphasized culture as potential to shape futures. Eaton (2016) has analysed the role of 'industrial culture' in Swidler's (1986) 'cultural toolkit' framework, which states that culture 'influences action not by providing the ultimate values toward which action is oriented, but by shaping a repertoire or 'toolkit' of habits, skills, and styles from which people construct 'strategies of action' (Swidler 1986:273). Eaton underlines that industrial culture "refers to the reservoir of cultural meanings and practices actors construct around existing local resource" extraction respectively development (Eaton 2016:77). Community's industrial culture "includes its repertoire of stories, ideas, meanings, orientations, practices and other cultural resources" that are (re-)constructed around industrial development, its environmental legacy "in and around that locale" (Eaton 2016:85). From a spatial perspective these notions are linked to David Harvey's concept of 'struc- tural coherence' that states (among other factors), that regional class alliances (here read as tied to specific modes of production in space) constitute regional spaces of action within global capitalism (Jessop 2006).

From a more micro-economic view-point, the concept of 'tacit knowledge' has to be considered regarding a broader understanding of the potential of industrial culture recurring on existing knowledge, competences, and habits. Tacit knowledge - which is not codified - can be defined as skills, experiences and ideas that people have in their minds and that are difficult to access (Chugh et al. 2015). In Polanyi's well-known phrase 'we can know more than we can tell' (Polanyi 1958:4), the core of the distinction between tacit and explicit, codified knowledge is outlined. However, both types of knowledge are complementary. Tacit knowledge is controlled informally by collectives of workers and is linked to a place, while codified knowledge is controlled by managers and companies and able to circulate. Gourlay (2002) describes tacit knowledge as highly personal and context specific and deeply rooted in individual experiences, ideas, values and emotions. Tacit knowledge could be transmitted only through social interactions, net- 
working, and personal contact. In the light of outmigration from peripheral (post-)industrial regions and in regard to existing local industrial culture, it is therefore important to maintain contact with local representatives of (former) industries to secure knowledge, and, the - at least once having existed pioneering spirit.

In another reference, Crevoisier and Jeannerat (2009) state that the central question in a globalized society is how to mobilize knowledge existing somewhere else and to combine it with local knowledge (anchoring capacity). They add that numerous innovations take place often rather via socio-cultural dynamics than techno-scientific ones and conclude that the growth of cultural industries requires above all socio-cultural knowledge. Innovative milieu approaches make it possible to understand that development could be initiated by local, small territorial entities. Thus, remarkable knowledge dynamic could be recreated 'from the bottom-up' (cf. Barski \& Zathey 2018, this issue) and therefore it is a chance for peripheral (post-)industrial regions to awake to resources for regional development.

In summary, the concept and understanding of 'Industrial Culture' has seen some waves and changes in interpretation and definition across different time periods and national contexts. One classic approach is focusing on industrial heritage, including the preservation and re-use of old industrial sites and landscapes, e.g. in the form of museums. But what we can conclude from the research strands highlighted above is that the intangible, culturebased heritage and present of industrial production in society is equally (maybe even more) important to (post-)industrialised places, as it holds the potential to unlock new development opportunities and connect to people in place (cf. Fig. 1).

Based on these reflections, our basic understanding of industrial culture is that it is grounded in the specific institutionalised routines of industrial structures, their incorporated conventions, beliefs and production patterns, as well as the interlinked social factors beyond the factory itself.It addresses a special, place-bound cultural setting, a concentration of specific expertise, attitudes, values, and traditions.It is a trans-disciplinary, societal concept, which builds on tangible, material and intangible, nonmaterial elements originating from the sphere of industrial production in past, present and future. We would add to this definition, that this term holds the possibility to serve as a frame for future regional development strategies in (post-) industrial regions, especially in small and medium-sized towns, where knowledge-intensive service sector is not as developed as in major cities. According to this understanding, industrial culture is a dynamic phe- nomenon, based on social interaction and networking, while being place-bound and locally embedded. Previous research has already highlighted this broader understanding in regional development aspects, including also intangible aspects of the industrial past, focussing on skills, traditions and mind-sets (Harfst \& Wirth 2014; Harfst \& Fischer 2015), thereby following rather the English understanding of 'Industrial Culture', as a whole 'milieu' of social and physical remains are included (Byrne 2002). Eaton (2016:77) underlines that "industrial cultures are both past and present oriented" (Eaton 2016:77), as actors construct critical interpretations for both the legacy of previous and implications for future development. Taking this point further, we will argue in the next section about the relevance of industrial culture for regional development policies.

\section{Relevance of industrial culture in a (post-) industrial Europe}

Having outlined the different academic approaches to industrial culture, as well as having charted the changing character of the term, we also have put forward our own definition. But why do we as editors hold this term relevant for the spatial development of certain European regions? What are the framework conditions that give industrial culture its current importance?

In the context of major societal and economic changes, a widely held academic view is that Europe's industrial societies have transformed over the past decades towards internationally networked information societies increasingly based on knowledge, creativity and innovation as main assets for economic development (Castells 2000). However, these developments are affecting regions in very different and uneven ways (among others Farole et al. 2011; Hadjimichalis \& Hudson 2014). Urban agglomerations are often seen as major hubs in this development, as preferred locations for innovation and the knowledge economy (d'Ovidio 2010; Musterd \& Gritsai 2010), and as gateways to international networks (Sassen 2002), often merging manufacturing and design sectors. By contrast, small and medium-sized towns in rural environments often continue to have a small industrial base, but they do not succeed in attracting the knowledge economy in the same way as large cities (Geppert \& Stephan 2008; Harfst \& Wirth 2014; Capello et al. 2015; Lang et al. 2015). This results in a range of interconnected problems in peripheral regions, such as 'brain-drain' or low innovation capacity (e.g. 
Wirth et al. 2012), endangering the aim of a territorial cohesion in the EU (EU Ministers of Spatial Planning and Territorial Development 2011).

Although the importance of industries in such regions is generally rather understated research-wise, the attention to industrial production in Europe is increasing in the aftermath of the financial crisis 2007-2008. In a communication to the EU Parliament, the EU Commission 'considers that a strong industrial base will be of key importance for Europe's economic recovery and competitiveness' (European Commission 2014). In connection to this, the European Territorial Agenda 2020 demands a more focused approach towards place-based (territorial) potentials (EU Ministers of Spatial Planning and Territorial Development 2011). Here the second, knowledge-based aspect of industrial culture becomes crucial: the existing competences, traditions and knowledge of old-industrialised regions and its people (cf. Pipan 2018, this issue). During early industrialisation, industrialised regions were drivers of change, being entrepreneurial and innovative in developing specific mind-sets and skills in their field of production (Sadler \& Thompson 2001). These intangible remains of the industrial age form an important, but so far neglected resource in reindustrialisation efforts. In a similar vein, national and regional governments set up strategies for reindustrialisation through the development of 'Industry 4.0' or smart specialisation strategies, both aiming at a valorisation of industrial labour.

This transition towards Industry 4.0 is increasingly manifesting itself in the European economic landscape. This is visible in the (slow) disappearance of linear production processes, which have characterized the classic manufacturing industries for a long time, also changing the very basic principles of linear production (e.g. reliance on fossil fuels). Rather it becomes visible that the factory of the future will be typified by digitalization. Next to the omnipresence of ICT and internet, the factory of the future is part of a network, where it interacts with other players (e.g. customers) in its search for consequent innovation and optimization of products and the production processes. Each step of the process in the factory is strongly linked to sustainability, the employee is considered more as a person with certain wishes towards working conditions (Vision 2050:30-31). Circular principles - which have evolved in social trends that are at the basis of new consumption and business models - are now emerging in the Industry 4.0 context. The transition manifests itself in the growth and increasing application of innovative technologies/digitalization, energy efficiency, circular econ- omy, product-service systems (PSS) and sharingeconomy, leading to new value chains (Rifkin 2001). This requires a new way of thinking and acting of both the producer and consumer. However, despite the fact that the industrial 'renaissance' appears very profound, the industrial pioneer culture present in many European regions still closely relates to it. The community feeling and solidarity that is present in the blue-collar milieu is a perfect condition for developing sharing economies.

\section{Industrial culture as a tool for regional development outside agglomeration areas}

Industrial culture in its broader sense has also gained an unprecedented popularity outside the economic sector in the recent decades. Not only several world heritage titles addressing the industrial past (e.g. Völklinger Hütte in Germany, Dolní Vítkovice in the Czech Republic) and initiatives like the European Route for Industrial Heritage (ERIH), but also spectacular events like Cultural Capital in the Ruhr 2012 or the music festival Colours of Ostrava celebrate a (past) time of intensive industrial mass production. 'All these features show a heightened interest in the industrial past and its remains, (ironically) after years of industrial decline in Europe and the Western countries in general, that stamped many of these places of structural change with a rustbelt image' (Harfst et al. 2016:49). This is one aspect of industrial culture, focusing on the cultural and heritage value of the industrial past. Here this cultural heritage has been identified in numerous EU strategies as an important driver of change (European Parliament DG IP 2013). The report of the Horizon 2020 Expert Group on Cultural Heritage suggests that lessons should be learnt from places where cultural heritage has been a positive economic, social and environmental driver. Innovative financing, new forms of governance, unified landscape management, public private partnerships, crowd-sourced funding, philanthropy and many other innovative and creative approaches might be taken to releasing the lockedup potential of Europe's heritage. The potential as a change driver is mainly distinguished in relation to the tourism sector, but also in the context of creating a joint European identity (Soyez 2015). Various scientific articles proof this relation, having re-enforced a trend by towns and cities to 'rediscover' their industrial heritage (i.e. Fleiss \& Strelow 2008), despite the often subdued value of industrial heritage as a tourism product (Hospers 2002). 
The main question for us as guest editors is now how to re-connect skills and knowledge of traditional industry with the demands of a globalised market, built on creativity and innovation - in other words how to activate the specific milieu of old-industrialised region to face new challenges. In agglomeration areas this task is certainly easier to tackle, with (world-) market access, creative classes, higher education institutions and industrial-base all to a certain degree in place (Camagni 1991). However, for Europe's (post-) industrialised regions that are situated outside agglomeration areas this question is especially difficult to answer. These regions often still possess highly competitive industrial units, albeit without the major employment effect for the region, they once had (Müller et al. 2005; Koutský et al. 2011). Nevertheless, such places and industries face specific problems in the described market conditions situated outside agglomeration areas (Jigoria-Oprea $\&$ Popa 2017).It means a stronger demand of local workforce and knowledge to remain competitive a challenging task for regions with high rates of outmigration, no higher education facilities and suffering from a bad image from the times of structural change (Wirth et al. 2012). Such specific challenges also include the negative image of industrial labour in many regions that have faced severe restructuring, especially among younger people (Strangleman 2001 or Strangleman et al. 2013), as well as institutional problems such as 'lock-in' and a general longing for a 'golden past', blocking the way to future development paths (Hudson 2005; Wirth et al. 2012; cf. Radu 2018, this issue). According to these challenges, we would like to identify some areas of intervention and further research for a more sustainable regional development by the utilization of the concept of industrial culture - also based on first, concrete project results from the afore mentioned InduCult2.0 project.

\section{The potential of industrial culture in regional development}

Utilising industrial culture in the context of regional development should have the potential for securing labour force, as many regions struggle with brain drain, demographic decline and ageing. Therefore, there is a need to motivate especially young people for staying in peripheral industrial regions based on new jobs through the opportunities emerging from digitalization and Industry 4.0. Developing approaches for binding the workforce closer to companies and likewise the companies to the regions, e.g. via corporate social and regional responsibility schemes (thereby also addressing social, cultural and environmental concerns) could be one way in this direction, but so far not many examples exist (Wust et al. 2017). Furthermore, in combination with specific local art a 'new' industrial culture could be developed that might strengthen the regional tourism and the potential of industrial tourism niche. This potential of tangible and intangible attributes of industrial age and cultural settings of industrial regions could break existing negative stereotypes of industry and industrial regions alike. Some examples have been realised, but their impact is scarcely analysed and evaluated yet. Additionally, industrial regions often have a range of certain assets and resources like mindsets, skills, traditions, and tacit knowledge (cf. Glorius \& Manz 2018, this issue) that could foster creative industries and pioneering spirit while reusing previous industrial buildings, e.g. as creative hubs (cf. Bosák et al. 2018, this issue). By no means, such strategies are exclusive to the bigger conurbations. But here again, research as so far mainly has focused on metropolitan settings, leaving a gap in the research regarding small- and medium-sized industrial towns.

From the brief outline above, it is highlighted why we as editors see industrial culture as an important potential for regional development linking the past, present, and the future development opportunities of (post-) industrial regions. Therefore, current definitions and concepts related to industrial culture must be reinterpreted and reinvented. This special issue contributes to the development of a dynamic forward-looking concept of 'industrial culture' in the context of regional development, as the individual contributions in this issue demonstrate.

\section{About the contributions in this special issue}

In his paper, Tomaž Pipan stresses the value of 'know-how in making' in the context of industrial culture. Based on the observations in Twente region in the Netherlands and the development in Third Italy, Pipan recalls that many industrial sites in the global north have witnessed a relocation of their production facilities to the global south. He argues that relocation also induced a loss of knowledge, and in particular a loss of know-how regarding the operation of production and assembly lines. This production-related knowledge is an integral component of industrial culture in individual regions. By drawing on recent examples of re-shoring 
of industrial production towards the global north, Pipan emphasizes that this know-how in production can be re-established. This re-industrialisation is an additional field of action complementing the often inefficient regional development approaches based on industrial heritage tourism.

Jan Barski and Maciej Zathey take industrialisation, deindustrialisation and reindustrialisation in Poland, and in Lower Silesia in particular, as a starting point for their paper. Their analysis uses statistical data on the regional level, which they use to demonstrate that Polish regions have taken different development paths since the end of WWII and after the post-socialist transition. Western Polish regions retained a functioning industrial base after the war, while industries in Eastern Poland had been destroyed. During the socialist period, major investments were located in the Central and Eastern Polish industrial sites and the Western Polish regions lacked financial support. This given, Western Poland's economy was in a comparably weak position at the starting moment of postsocialist transition. They point out that future development in industrial production, such as the increasing digitalisation and extensive inclusion of artificial intelligence will change the game. The future success of an industrial redevelopment will mainly depend on regions' capacities to adapt to these new and digital ways of industrial production. Barski and Zathey argue that one of the ways of recuperating have been cultural and social initiatives, which attempt to revitalise historic buildings, local culture, recreation and tourism, etc. complemented by bottom-up economic actions. In that context they refer to Porter (1998), who emphasized the importance of local tradition and cultural background as the fertile ground on which industrial clusters may flourish.

Birgit Glorius and Katja Manz report from the former industrial city of Chemnitz in Germany, where regional stakeholders try to develop their city, making use of the industrial past and its current remains. According to the authors, the approach is exemplary for the valorisation of industrial culture in many places across Europe, where the industrial past takes the form of a museumification. The main argument of the authors here is that this strategy falls short, because it neglects most often the perspective of today's inhabitants of these places. In a field experiment, both authors recorded this missing perspective of the local population in order to widen the view of industrial culture. By doing so, they are in line with the above-mentioned understanding of industrial culture as a set of local tacit knowledge stocks and pattern of beliefs, norms and values. Fur- thermore, they broaden the understanding of industrial culture by suggesting a concept, which also includes controversial and opposing narratives regarding the local industrial past and present. The authors summarise that these divergent perspectives on industrial culture must be taken into account when regions try to reinvent themselves and seek for the construction of a positive regional industrial identity.

Bianca Radu analyses the social characteristics of former mining communities in Romania and the strategies adopted by residents to overcome mine closure based on two case studies. The research was conducted in the northern part of Romania that was most affected by the mining and industrial restructuring in the country. Based on current research concepts Radu assumes that mining communities have particular characteristics that form a specific environment, labelled either as industrial culture, industrial atmosphere, mining culture or company town mentality. After restructuring the members of the researched communities perceived mining as dominating their identity. Socialized in a state-led culture, former miners expected the state institutions to provide them with jobs. In the end, migration was the main strategy adopted by the residents to overcome scarcity of jobs. Radu concludes that the characteristics of the mining communities shaped their trajectories after mining restructuring, but there are further important factors to be considered, like the quality of infrastructure, implemented redevelopment programmes and the distance to major urban centres. In the final contribution Bosák, Nováček and Slach discuss aspects of restructuring, brownfields, and industrial heritage against the background of the Czech city of Ostrava. Their aim is to assess the aspects significance both as a barrier and asset for future urban development. Their analysis comprises both intangible and tangible features of the industrial past, seeking the middle-ground between the two, meaning symbols, identities and images attached to tangible built structures. Via examples for Ostrava they include not only former buildings of production, but also supporting infrastructures connected to energy supply, transportation, waste treatment and amenities for workers, and their impacts on the urban structure of the whole city. Their analysis shows that these structures are major constraints for urban restructuring, and it takes new approaches to overcome and utilise the intrinsic features of the industrial past for the new needs of post-industrial development. The paper suggests that industrial heritage is an important point of self-reference in the city, albeit in a selective way. While remnants of the in- 
dustrial past from the 19th century have been included in 'heritage' by local policymakers, remnants of the socialist era industrialisation are still rejected.

All these contributions share the emphasis on the tangible and intangible dimensions of industrial culture. Only in combination of both of them, regional development can profit from making recourse to industrial culture. This also includes the consideration of possible lock-ins based on developed habits, traditions, and expectations (cf. Radu 2018, this issue). Furthermore, all authors stress the relevance of linking past industrial activities with current and future ones. A mere exploitation of past industrial heritage for the sector of tourism development is neither sufficient nor promising for a comprehensive regeneration of economic bases in deindustrialised European regions. Here, a reflection process needs to be launched, which should bring forth potential ways of establishing and maintaining an industrial base, be it by reshoring (cf. Pipan 2018, this issue), digitalization and the use of new technologies (cf. Barski \& Zathey 2018, this issue), or a mobilisation of regional identities (cf. Glorius \& Manz 2018, this issue). Further approaches might be conceivable; but the central insight remains: industrial culture is much more than a museum-like staging of the material artefacts of an industrial past (cf. Bosák et al. 2018, this issue).It includes the present and the future, and it respects the immaterial dimension, which is articulated in regional inhabitants' beliefs, habits, norms and values regarding the industrial production.

\section{Notes}

${ }^{1}$ The workshop included participants from Russia, Slovenia, Czech Republic, Poland, Germany and Austria. A short documentation is available online (www.geographie.uni-graz.at/en/research/research-groups/humangeographie-i/forschungsprojekte/inducult-20).

\section{References}

Barski J, Zathey M (2018) Post-transformation industry in Poland. Industrial and post-industrial culture in western border regions in history and in the future. GeoScape 12(1): 17-25.

Bosák V, Nováček A, Slach O (2018) Industrial heritage as an asset, barrier and creative challenge for development of old industrial cities: case study of Ostrava. GeoScape 12(1): 52-64.

Byrne D (2002) Industrial culture in a post-Industrial World: The case of the North East of England. City 6(3): 279-289.

Camagni R (Ed.) (1991) Innovation networks. Spatial perspectives. Belhaven, London.
Capello R, Caragliu A, Fratesi U (2015) Spatial heterogeneity in the costs of the economic crisis in Europe: are cities sources of regional resilience? Journal of Economic Geography 15(5): 951-972.

Castells M (2000) The rise of the network society. Blackwell, Oxford, Malden.

Chugh R, Wibowo S, Grandhi S (2015) Mandating the transfer of tacit knowledge in Australian universities. Journal of Organizational Knowledge Management, Article ID 297669.

Crevoisier O, Jeannerat H (2009) Territorial knowledge dynamics: from the proximity paradigm to multi-location milieus. European Planning Studies 17(8): 1223-1241.

d'Ovidio M (2010) Fashion and the city: social interaction and creativity in London and Milan. In: Vicari Haddock S (ed.), Brand-building: the creative city. A critical look at current concepts and practices, pp. 113-136.

Eaton WM (2016) What's the problem? How 'industrial culture' shapes community responses to proposed bioenergy development in northern Michigan, USA. Journal of Rural Studies 45: 76-87.

EU Ministers of Spatial Planning and Territorial Development (2011): 'Territorial Agenda of the European Union 2020'. [http://www.eu2011.hu/files/bveu/documents/TA2020.pdf; 31.03.2017].

European Commission (2014): 'For a European industrial renaissance - SWD (2014) 14 Final'. http://eur-lex.europa.eu/legalcontent/EN/TXT/PDF/?uri=CELEX:52014DC0014\&from=EN

European Parliament DG IP (2013): 'Industrial heritage and agri/rural tourism in Europe IPOL-TRAN ET'. Study report P/B/TRAN/FWC/2010-006/Lot5/C1/SC2. European Parliament, Brussels. [http://www.europarl.europa.eu/RegData/etudes /etudes/join/2013/495840/IPOL-TRAN_ET(2013)495840_EN.pdf; 31.03.2017].

Farole T, Rodriguez A, Storper M (2011) Cohesion policy in the European Union: growth, geography, institutions. Journal of Common Market Studies 49(5): 1089-1111.

Fleiss D, Strelow D (2008) Industriekultur-Tourismus - Der Neue Hoffnungsträger Für Essen-Katernberg. In: Schwarz A (ed.) Industriekultur, Image, Identität. Die Zeche Zollverein Und Der Wandel in Den Köpfen, pp. 221-260.

Geppert K, Stephan A (2008) Regional disparities in the European Union: convergence and agglomeration. Papers in Regional Science 87(2): 193-217.

Glaser H, Neudecker N, Ruppert W (eds.)(1980) Industriekultur in Nürnberg. Eine deutsche Stadt im Maschinenzeitalter. München.

Glaser H (1981) Maschinenwelt und Alltagsleben. Industriekultur in Deutschland vom Biedermeier bis zur Weimarer Republik, Frankfurt am Main.

Glorius B, Manz K (2018) Beyond the City of Modernism: a counter-narrative of industrial culture. GeoScape 12(1): 26-38.

Gourlay S (2002) Tacit knowledge, tacit knowing or behaving. In: 3rd European Organizational Knowledge, Learning and Capabilities Conference; 5-6 April 2002, Athens, Greece.

Hadjimichalis C, Hudson R (2014) Contemporary crisis across Europe and the crisis of regional development theories. Regional Studies 48(1): 208-218.

Harfst J, Wirth P (2014) Zur Bedeutung endogener Potenziale in klein- und mittelstädtisch geprägten Regionen - Überlegungen vor dem Hintergrund der Territorialen Agenda 2020. Raumforschung und Raumordnung 72(6): 463-475. 
Harfst J, Fischer W (2015) Innovative Heritage-Based Products: A Transnational Manual. 1st ed. Graz: University Graz. [https://www.researchgate.net/publication/295400955_Innovative Heritage-based Products - A transnational manual; 31.03.2017].

Harfst J, Pizzera J, Simic D (2016) Industrial heritage, cultural resources of current industries and creative pioneers - utilizing industrial culture in Central Europe. Revija za Geografijo 11(2).

Hospers G-J (2002) Industrial heritage tourism and regional restructuring in the European Union. European Planning Studies 10(3): 397.

Hudson R (2005) Re-thinking change in old industrial regions: reflecting on the experiences of North East England. Environment and planning A 37(4): 581-596.

Jessop B (2006) On spatio-temporal fixes. In: Castree N, Gregory D (eds.) David Harvey - a critical reader, pp. 152-166.

Jigoria-Oprea L, Popa N (2017) Industrial brownfields: an unsolved problem in post-socialist cities. A comparison between two mono industrial cities: Reşița (Romania) and Pančevo (Serbia). Urban Studies 54(12): 2719-2738.

Koutsky J, Slach O, Boruta T (2011) Restructuring economies of old industrial regions - local tradition, global trends. In: The scale of globalization. Think globally, act locally, change in dividually in the 21st Century, pp. 166-173.

Lang T, Henn S, Sgibnev W, Ehrlich K (eds.) (2015) Understanding geographies of polarization and peripheralization. Perspectives from Central and Eastern Europe and beyond. Palgrave Macmillan, New York.

Müller B, Finka M, Lintz G (2005 eds.) Rise and decline of industry in Central and Eastern Europe. Springer, Berlin.

Musterd S, Gritsai O (2010): Conditions for 'Creative Knowledge Cities': findings from a comparison between 13 European metropolises. 'Going creative' - an option for all European cities? AISSR, University of Amsterdam, Amsterdam.

Pipan T (2018) Neo-industrialization Models and Industrial Culture of Small Towns. GeoScape 12(1): 10-16.

Pirke K (2010) Industriekultur und ihre Bedeutung für gesellschaftlich-planerische Prozesse am Beispiel der Erhebung von industriekulturellen Potenzialen: Plädoyer für eine Angewandte Industriekulturforschung in der Region. Mitteilungsblatt des Instituts für Soziale Bewegung 44: 171-186.

Polanyi M (1958) Personal knowledge: towards a post-critical philosophy. University of Chicago Press, Chicago.

Porter M E (1998) Competitive advantage. Creating and sustaining superior performance: with a new introduction. Free Press, New York, London.

Radu B (2018) Industrial Culture of Former Mining Communities from Romania. GeoScape 12(1): 39-51.
Rauner F, Ruth K (1996) Industrial culture and production - towards a new research approach. In: Rasmussen L, Rauner F (eds) (1996) Industrial cultures and production. Understanding Competitiveness, pp. 3-17.

Rautenberg M (2012) Industrial heritage, regeneration of cities and public policies in the 1990s: elements of a French/British comparison. International Journal of Heritage Studies 18(5): 513-525

Rifkin J (2001) The Age of Access: The new culture of hypercapitalism. Where all of life is paid-for experience. J.P. Tarcher/Putnam, New York.

Sadler D, Thompson J (2001) In search of regional industrial culture: The role of labour organisations in old industrial regions. Antipode 33 (4): 660-686.

Sassen S (2002) (Ed.) Global Networks, Linked Cities. Routledge, New York.

Soyez D (2015) Europäische Industriekultur Als Touristisches Destinationspotenzial. Zeitschrift Für Wirtschaftsgeographie 50(1): 75-84.

Strangleman T. (2001) Networks, place and identities in postIndustrial mining communities. International Journal of Urban and Regional Research 25(2): 253-267.

Strangleman T, Rhodes J, Linkon S (2013) Introduction to crumbling cultures: Deindustrialisation, class and memory. International Labour and Working Class History 84: 7-22.

Swidler A (1986) Culture in action. Symbols and strategies. American Sociological Review 51: 273-286.

Vision 2050, a long-term strategy for Flanders' - study of the Flemish Government (2016), http://www.vlaanderen.be/int/europese-unie/en/news/vision-2050-long-termstrategy-flanders [20.05.2017]

Williams R (1980): Problems in materialism and culture. Verso, London.

Wirth P, Cernic-Mali B, Fischer W (eds.) (2012) Post-mining regions in Central Europe - problems, potentials, possibilities. OEKOM, München.

Wissenschaftlicher Beirat für Industriekultur in Sachsen (eds.) (2010): Industriekultur in Sachsen. Handlungsempfehlungen des Wissenschaftlichen Beirates für Industriekultur in Sachsen. Freiberg/Dresden, http://www.kdfs.de/do/314.0.pdf [31.03.2017].

Wust A, Lang T, Haunstein S, Mäekivi E (2017) Industrial culture, labour force and companies - Academic recommendations for practical intervention on how to deploy Industrial Culture for securing labour force and strengthening the regional ties of companies. InduCult2.0 working paper. Accessible via www.ifleipzig.de/filead$\mathrm{min} /$ user upload/Forschung/Raumproduktionen/CE31 InduCult_PP2_PR2_Annex1_D-3-1-2_input_paper_web.pdf 